\title{
An ultrastructural study of Helicobacter mustelae and evidence of a specific association with gastric mucosa
}

\author{
JANI O'ROURKE, A. LEE and J. G. FOX* \\ School of Microbiology and Immunology, University of New South Wales, Sydney, NSW, Australia 2033 and \\ "Division of Comparative Medicine, Massachusetts Institute of Technology, Cambridge, MA, USA 02139
}

\begin{abstract}
Summary. The ultrastructure of Helicobacter mustelae, a natural inhabitant of the ferret stomach, has been studied and compared with the human gastroduodenal pathogen $H$. pylori. $H$. mustelae is a short, slightly curved rod, $2 \mu \mathrm{m} \times 0.5 \mu \mathrm{m}$, with four or more sheathed flagella. The most common flagellar configuration is a single flagellum at one terminus, bipolar arrangement at the other end and a lateral flagellum. Dense inclusion bodies were observed below the flagellar insertion sites. It is suggested that this configuration is a specialised adaptation to motility in a viscous environment. On examination of the ferret gastric mucosa, similarities to $H$. pylori were observed such as adherence to gastric tissue and the formation of adhesion pedestals. However, unlike $H$. pylori, significant numbers of bacteria were intracellular. Furthermore, a much greater proportion of $H$. mustelae were attached to the mucosa with few bacteria lying free in the mucus, as is seen with $H$. pylori. It is concluded that the ferret is an important model for the study of adherence of bacteria to gastric mucosa and their possible role in peptic ulceration.
\end{abstract}

\section{Introduction}

The isolation of a Campylobacter-like organism from the human stomach in 1983 focused attention on what was thought to be a barren, hostile environment-the gastric mucosa. ${ }^{1}$ Taxonomic studies on this bacterium have shown that it has different characteristics to Campylobacter spp., resulting in the creation of a new genus, Helicobacter; the human isolate is now named $H$. pylori. Re-examination of the early literature has revealed the existence of bacteria in the stomachs of many animal species and man. ${ }^{2-5}$ With techniques for culture of $H$. pylori, gastric organisms have been isolated from non-human primates, ferrets, dogs and cats. ${ }^{6-10}$ The isolates from ferrets and cats are morphologically distinct from $H$. pylori and these observations have resulted in the creation of two new species. H. mustelae ${ }^{11}$ and $H$. felis. ${ }^{12}$

$H$. mustelae is a natural inhabitant of the ferret stomach. Like $H$. pylori, it has a limited host range and appeared, in preliminary studies, to adhere to the gastric epithelium. Significantly, ferrets are prone to peptic ulceration and both gastric and duodenal ulcers have been reported. ${ }^{9} \mathrm{H}$. mustelae colonises the gastric mucosa in a similar way to $H$.pylori, but the bacterium has a very different morphology; although the spiral morphology has been proposed as a specific adaptation to survival in gastric mucus, $H$. mustelae must have acquired some other survival trait.
The purpose of this study was to make a detailed examination of the ultrastructure of $H$. mustelae both in vitro and in vivo and to gain further insights as to its association with gastric mucosal surfaces.

\section{Materials and methods}

\section{Bacterial strains}

H. mustelae isolates ATCC 43773 and NCTC 12032 were used for ultrastructure analysis. All cultures were grown on Blood Agar Base No. 2 (Oxoid), supplemented with horse blood, $5 \% \mathrm{v} / \mathrm{v}$, incubated under micro-aerophilic conditions for $48 \mathrm{~h}$ at $37^{\circ} \mathrm{C}$ as previously described. ${ }^{9}$ Bacteria were harvested from plates and either stained with sodium phosphotungstate $2 \%$ containing bacitracin $0.01 \%$ or transferred to Karnovsky's fixative ${ }^{13}$ plus ruthenium red (Sigma) $0.5 \%$ and subsequently embedded in Noble agar $2 \%$.

\section{Animals}

Ten adult female ferrets were obtained from Marshall Farms, North Rose, NY and housed as previously described. ${ }^{14}$ Biopsy specimens were obtained from the stomachs of the animals and placed in Karnovsky's fixative containing ruthenium red $0.5 \%$.

\section{Electronmicroscopy}

The bacterial preparations from cultures and animals were post-fixed in osmium tetroxide and uranyl 

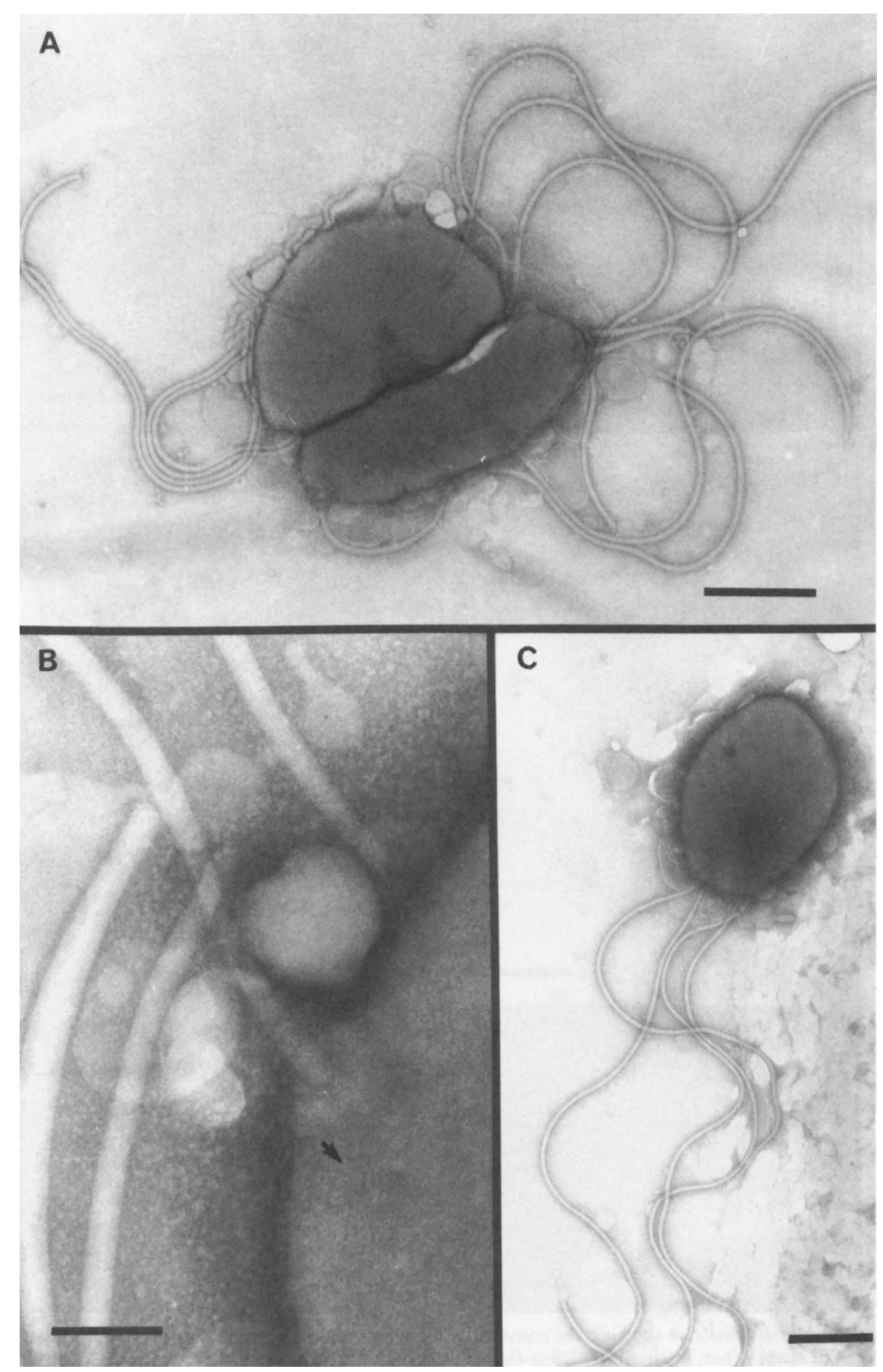

Fig. 1. Negatively stained preparations of $H$. mustelae cultures showing (A) polar and lateral flagella configuration (bar, $0.5 \mu \mathrm{m}) ;(\mathbf{B})$ regular array of circular structures $(\rightarrow)$ (bar, $0.1 \mu \mathrm{m}) ;(C)$ coccoid forms (bar, $0.5 \mu \mathrm{m})$.

acetate and embedded as described previously. ${ }^{10} \mathrm{Nega}$ tive stains and thin sections $(70-80 \mathrm{~nm})$ of the bacteria and gastric tissue were examined with an Hitachi $\mathrm{H}$ 7000 transmission electronmicroscope. Ultra-thin sections were cut with a Reichart Jung Ultramicrotome (Ultracut E) with the section thickness set at $20 \mathrm{~nm}$. Sections were collected on to a 400 mesh grid, stained overnight with uranyl acetate and then lead citrate for 5 min. Before examination with an Hitachi H 7000 electronmicroscope, grids were carbon coated on both sides for stability. Freeze-dried and freeze-etched samples were prepared as described previously ${ }^{10}$ and examined with a Phillips 300 transmission electronmicroscope.

\section{Results}

\section{In-vitro preparations}

H. mustelae from cultures was found to be a short, slightly curved rod, $2 \mu \mathrm{m} \times 0.5 \mu \mathrm{m}$, with four or more polar and lateral sheathed flagella as reported previously. ${ }^{9}$ Examination of a large number of negatively stained preparations revealed that the most common 


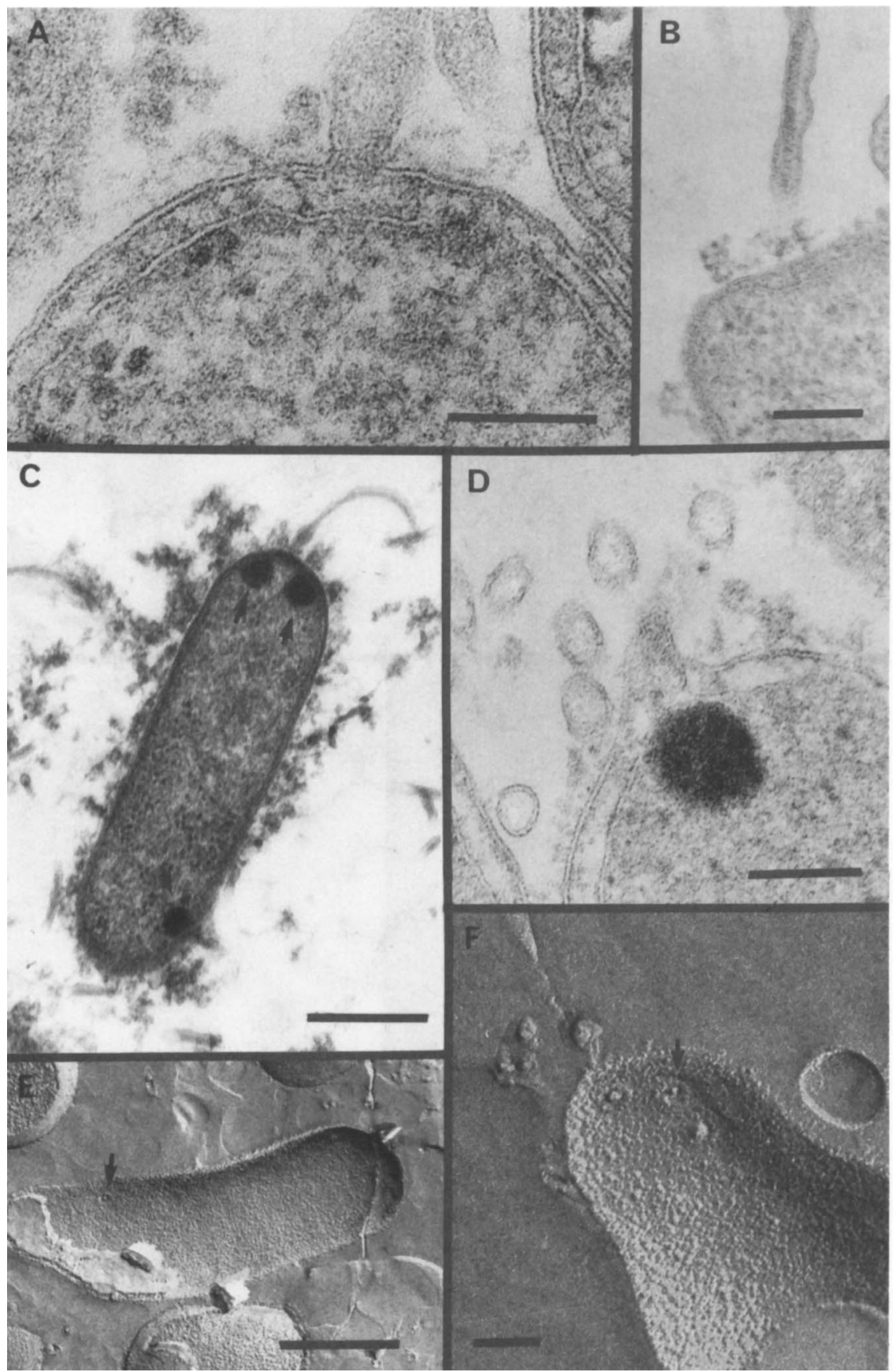

Fig. 2. (A) Ultra-thin section of $H$. mustelae showing the conventional gram-negative cell wall arrangement and the continuity of the outer membrane with the flagellar sheath (bar, $0 \cdot 1 \mu \mathrm{m}$ ). (B) Ultra-thin section of the sheathed flagella showing the central core (bar, $0.1 \mu \mathrm{m}$ ). (C) Thin section of $H$. mustelae showing electron-dense bodies located beneath the flagellar insertion points $(\rightarrow)$ (bar, $0.5 \mu$ m). (D) Ultra-thin section showing the flagella connecting to an electron-dense body (bar, $0 \cdot 1 \mu \mathrm{m}$ ). (E) Freeze-fracture preparation of $H$. mustelae showing concave structures associated with lateral flagella (bar, $0.5 \mu \mathrm{m}$ ). (F) Freeze-fracture preparation of $H$. mustelae showing concave structures associated with terminal fiagella (bar, $0.5 \mu \mathrm{m}$ ).

flagellar configuration was a single polar flagellum at one terminus and bipolar flagella at the other terminus together with a lateral flagellum (fig. 1A). Higher magnifications revealed that the surface was covered with a regular array of circular structures, $8 \mathrm{~nm}$ in diameter. In preparations in which the outer membrane appeared distorted, this array was still visible; however, it did not appear on the flagella (fig. 1B). The insertion points of the flagella, visible in some preparations, measured $80 \mathrm{~nm} \times 100 \mathrm{~nm}$ (fig. 1B). In only one of the negatively stained preparations were paddle-like structures seen at the end of the flagella. Coccoid bacterial forms were observed in which the flagella were located at one end (fig. 1C).

Sections of the bacterial cells showed the ultrastructure typical of gram-negative organisms, i.e., an outer membrane and a plasma membrane separated by a periplasmic space with a total thickness of $30 \mathrm{~nm}$ (fig. 2A). The flagella were sheathed with an external diameter of $32-40 \mathrm{~nm}$ and an internal core diameter of 14-17 nm (fig. 2B). Ultra-thin sections showed that the outer membrane of the cell wall was continuous with the flagellar sheath (fig. 2A).

A unique structural feature was found in the $H$. 


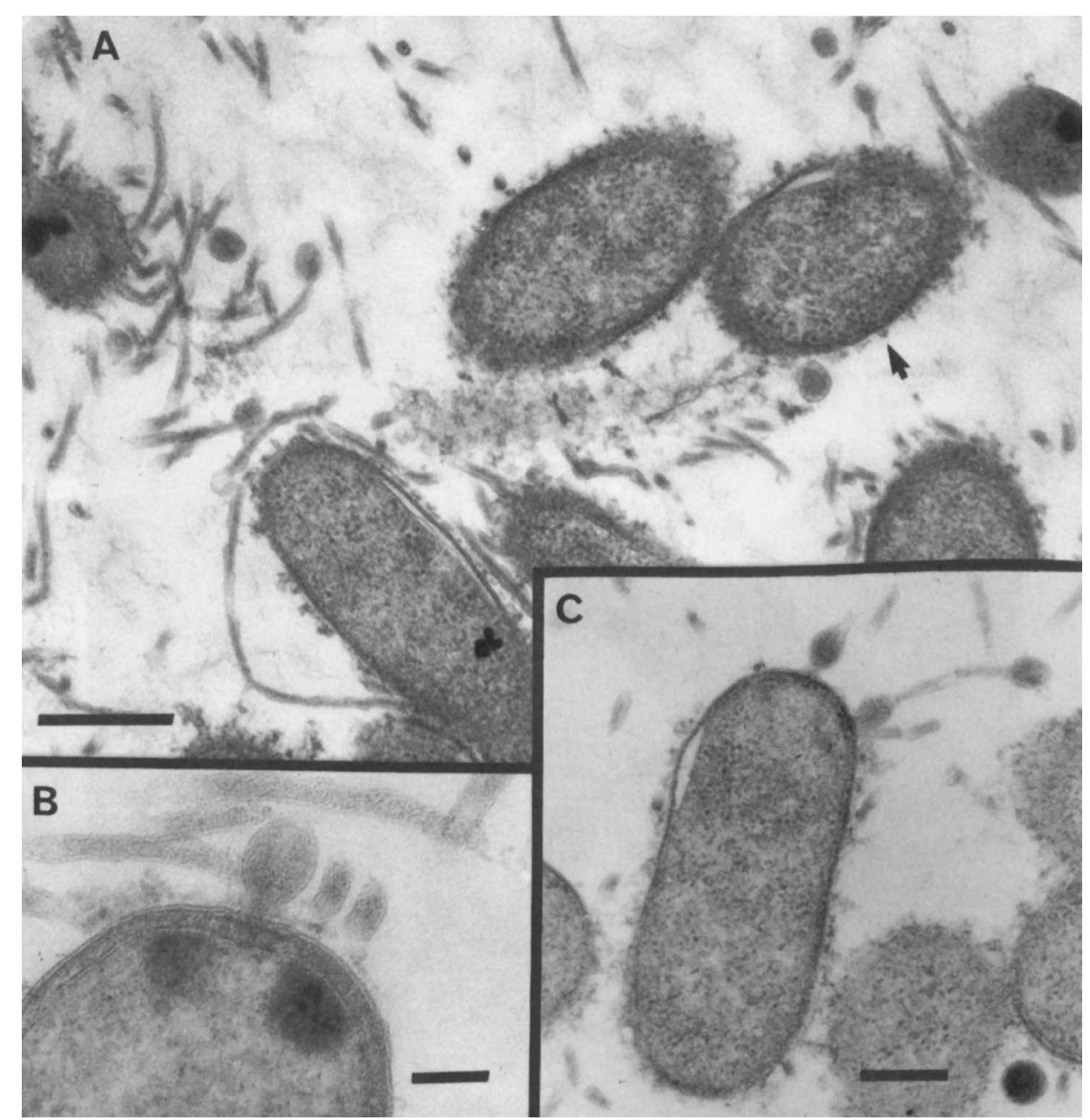

Fig. 3. Thin sections of $H$. mustelae cultures showing (A) glycocalyx external to the outer membrane $\rightarrow$ and occasional paddle-like structures (bar, $0.5 \mu \mathrm{m}$ ); (B) and (C) paddle-like structures located very close to the cell membrane (bars, $0.1 \mu \mathrm{m}$ and $0.25 \mu \mathrm{m}$, respectively).

mustelae preparations. An electron dense area or inclusion body, $80 \mathrm{~nm} \times 100 \mathrm{~nm}$, was observed (fig. 2C) adjacent to most of the flagellar insertion points and in some instances directly beneath them. Occasionally, flagella were seen penetrating the peptidoglycan layer and connecting with this electron-dense area (fig. 2D). This feature was found only in terminal, subterminal or lateral areas corresponding to the typical flagellar arrangement and was located in the cytoplasm below the plasma membrane wall.

Concave structures at lateral (fig. 2E) and terminal regions (fig. 2F) of the cell were seen in freeze fractures of $H$. mustelae. They were $30-42 \mathrm{~nm}$ in diameter, often with raised centres. Glycocalyx, $25 \mathrm{~nm} \times 50 \mathrm{~nm}$ thick, external to the outer membrane was also evident (fig. $3 \mathrm{~A})$. In many instances paddles, oval $(80 \mathrm{~nm} \times 100 \mathrm{~nm})$ and circular (110-120 nm in diameter) in shape, were observed (fig. 3B). An outer membrane was visible on these structures; however, it was impossible to determine the location of the paddles due to the procedures prior to electronmicroscopy. Often the paddles, or a thickening of the flagella, were observed within nanometers of the outer wall of the cell (figs. 3B and $\mathrm{C}$ ).

\section{In-vivo preparations}

Examination of semi-thin sections $(0.5 \mu \mathrm{m})$ of ferret gastric tissue showed bacteria localised within the gastric pits with little evidence of bacteria on the external surface or in the overlying mucus layer. Electronmicroscopy revealed a very close association of the bacteria with the epithelial cells (fig. 4). Bacteria were found alongside microvilli (fig. 5A), aligning themselves along the surface of the epithelium (fig. 5B), perpendicular to the surface of the epithelial cells and, in some instances, penetrating these cells (fig. 5C). Extensive loss of microvilli was seen and in such denuded areas, occasional adhesion pedestals were visible (fig. 5D). Some organisms were undergoing endocytosis (fig. 5E) and localised within membrane-bound inclusions inside the epithelial cells (fig. $5 \mathrm{~F}$ ).

Bacterial cells were also seen next to intercellular junctions; however, they did not appear to show a particular disposition for this site as has been reported for $H$. pylori. ${ }^{15,16}$ A fibrous-like matrix or glycocalyx was apparent between the epithelial and bacterial cells. This formed a very dense matrix when the two surfaces were very close together (fig. 5D), or showed more 


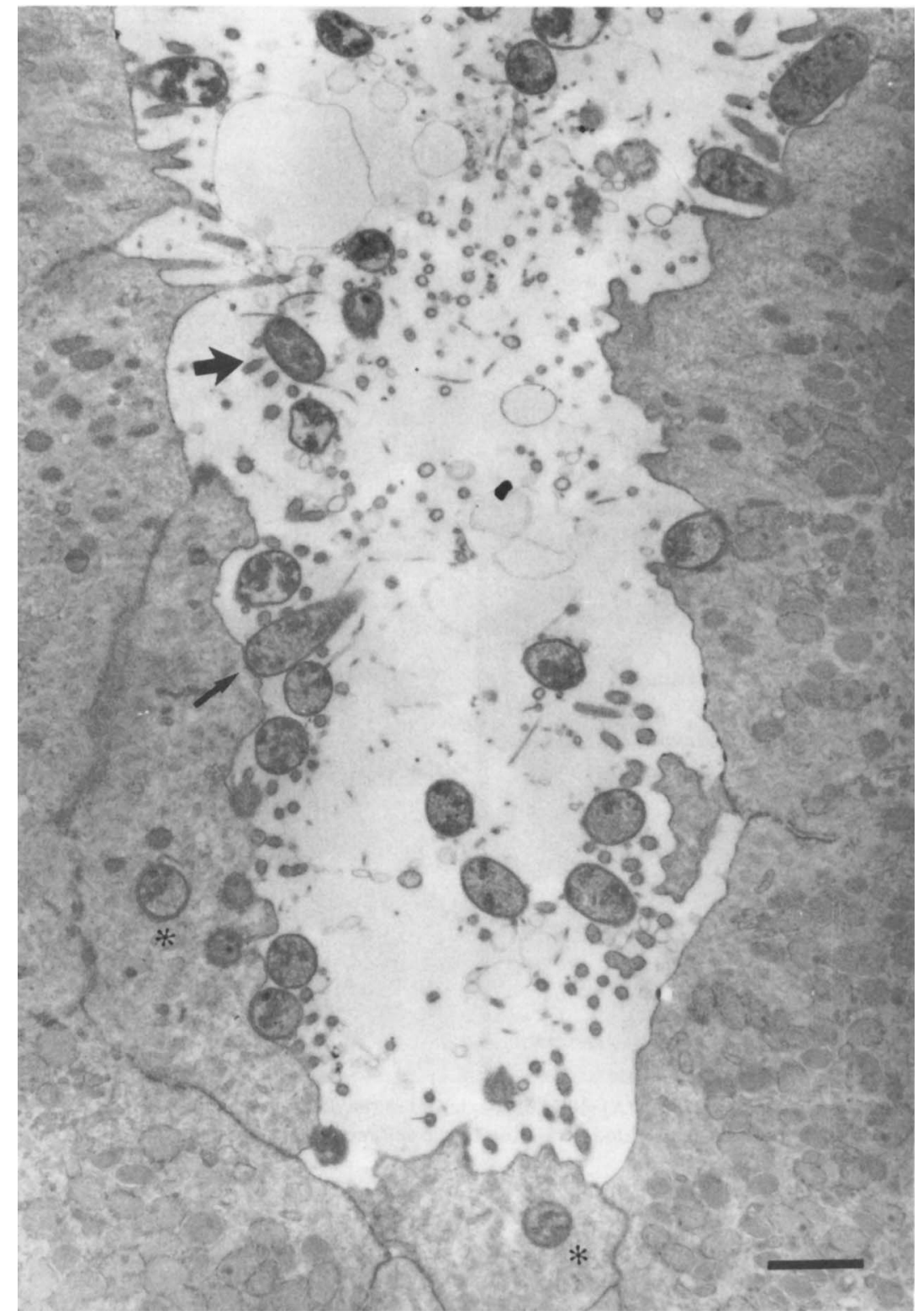

Fig. 4. Thin section of a ferret antral gastric pit showing the location of the bacteria. Note a bacterium apparently moving towards the epithelium surface in a "cartwheel-like" fashion ( $\rightarrow$ ), close association of the bacteria with the epithelial surface including the formation of adhesion pedestals $\left(\rightarrow\right.$ ) and endocytosed bacteria $\left({ }^{*}\right)$ (bar, $\left.1.0 \mu \mathrm{m}\right)$.

fibrous strands, especially when the bacterial cells were aligning with microvilli (fig. 5A). On one occasion a bacterial cell with flagella in a "cartwheel"-like format (fig. 4) was observed in a gastric pit. The electrondense areas near the flagellar insertion points, as described above were also visible on the bacteria in vivo.

\section{Discussion}

The mucus-associated epithelial surfaces of man and animals have been shown to contain large numbers of bacteria, many of which have a spiral or helical morphology which is thought to be advantageous in a viscous environment. ${ }^{17,18}$ The recent isolation of three different bacteria from this area ${ }^{1,9,10}$ has generated a new genus, Helicobacter. ${ }^{19,20}$ Their association with gastric disease resulted in extensive studies into the possible mechanisms of pathogenicity and the factors which may allow these organisms to colonise such a harsh environment. With the exception of $H$. mustelae, members of the Helicobacter genus and the proposed "Gastrospirillum hominis" ${ }^{21}$ (presently maintained only in vivo ${ }^{22}$ ) share characteristics in common with other mucosa-associated organisms, namely, a spiral or helical morphology and motility by means of polar or bipolar flagella. ${ }^{7,10,22}$ In contrast, $H$. mustelae is a small, curved rod with polar and lateral flagella. ${ }^{9}$

Although variations do occur, $H$. mustelae appears to have a uniform configuration of polar or subterminal and lateral flagella. This configuration is rare amongst bacterial species ${ }^{23}$ and we propose that this rare flagellar configuration compensates for their rodshaped morphology and allows passage through a viscous environment, such as mucus. Indeed, examination of motile cultures under phase contrast microscopy reveals an unusual spinning type motility. 


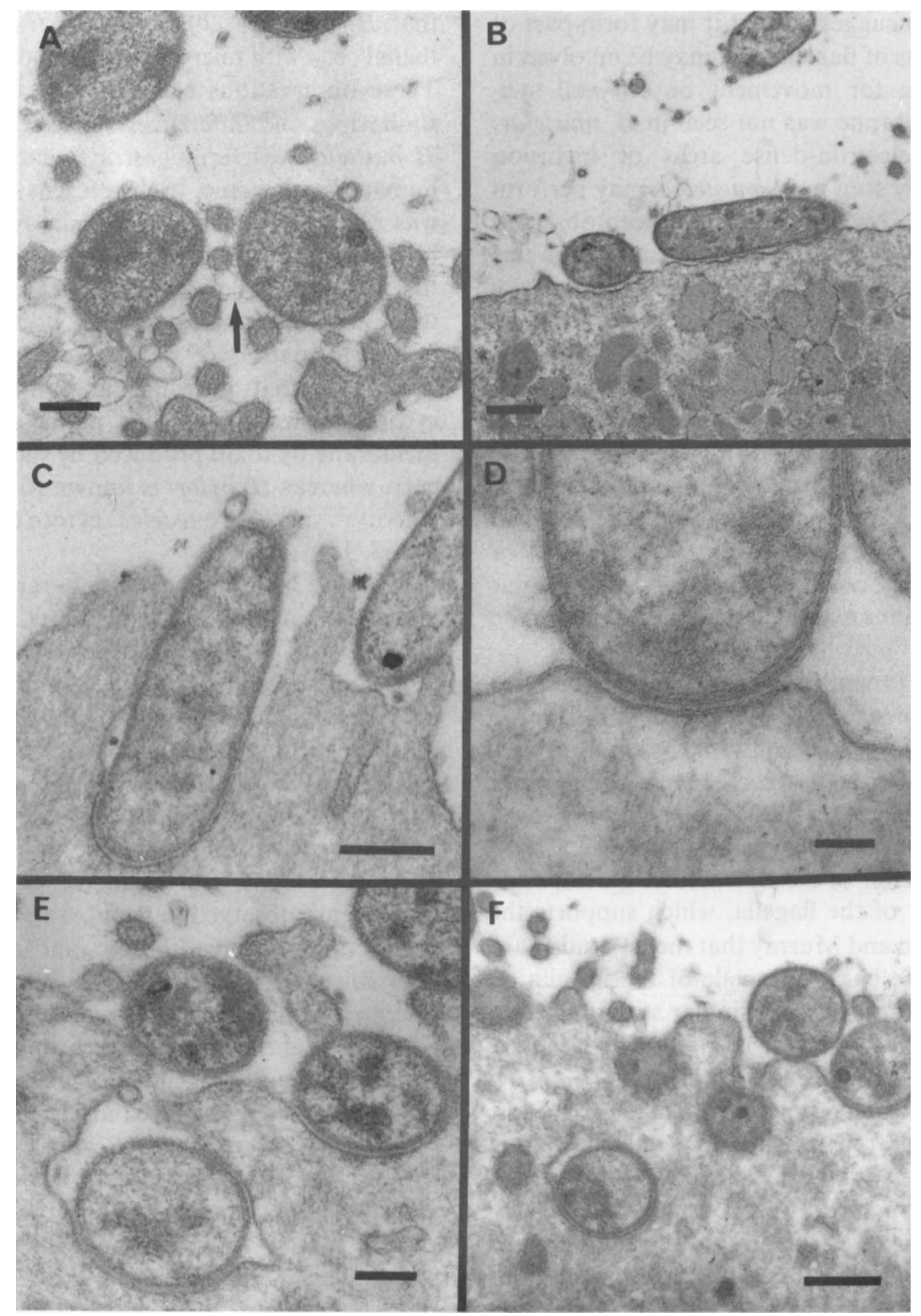

Fig. 5. Higher magnification of sections of ferret gastric tissue showing: (A) glycocalyx between bacteria and microvilli $(\rightarrow)($ bar, $0.25 \mu \mathrm{m})$; (B) bacterium aligning on the surface of an epithelial cell (bar, $0.5 \mu \mathrm{m})$; (C) bacteria penetrating into epithelial cells (bar, $0.5 \mu \mathrm{m}) ;($ D) formation of an adhesion pedestal (bar, $0.1 \mu \mathrm{m})$; (E) a bacterium undergoing endocytosis (bar, $0.25 \mu \mathrm{m})$; (F) bacteria located in membrane bound inclusions (bar, $0.25 \mu \mathrm{m}$ ).

This notion is supported by the studies of Greenberg and Canole-Parola in which they examined the motility of spiral-shaped and rod-shaped bacteria $; 24,25$ they demonstrated that the spiral morphology of Spirillum spp. and spirochaetes allowed them greater mobility in viscous environments. We have confirmed such observations with Campylobacter jejuni ${ }^{15,26}$ and H. pylori. ${ }^{15}$ Greenberg and Canole-Parola ${ }^{24}$ selected an organism (strain PFR-3) that was able to move through agar. This bacterium was shown to have the same rare flagellar configuration of $H$. mustelae, i.e., lateral and polar flagella. Strain PFR-3 attained a maximum speed in excess of the spirochaetes and Spirillum spp. but less than that of E. coli which has peritrichous flagella. However, this bacterium had a minimum immobilising viscosity (MIV), i.e., a velocity that stops the translational movement of cells, far in excess of all the organisms studied, including $E$. coli.

The basic structure of flagella is well documented. ${ }^{27,28}$ Briefly, they consist of a filament and hook, connected to a basal body consisting of a series of disks located in the outer membrane and peptidoglycan layers (the $L$ and $P$ rings) and within and below the plasma membrane (the $\mathrm{S}$ and $\mathrm{M}$ rings). Electrondense areas or "blebs" have been observed in Aquaspirillum spp. and Spirillum spp. in the cytoplasmic side of the plasma membrane ${ }^{29,30}$ and it has been suggested that these are associated with the $S$ and $M$ rings of the flagellar complex. Another feature commonly observed in bacteria with polar flagella, including $H$. pylori, is the so-called polar membrane. The precise function of this membrane is not known, 
though it has been suggested that it may form part of the basal apparatus of flagella or it may be involved in energy production for movement or cell-wall synthesis. ${ }^{31}$ This membrane was not seen in $H$. mustelae. The very large electron-dense areas or inclusion bodies, consistently seen in $H$. mustelae, may perform similar functions. This feature has not been observed in $H$. pylori or $H$. felis. The size and nature of this structure, as seen in $H$. mustelae, could reflect a heavy duty flagellar anchor necessary for the type of rotation exhibited by this organism.

The dimensions of the flagella of $H$. mustelae, their insertion points and the surface array correlate with results reported for $H$. pylori and $H$. felis. ${ }^{10,32}$ The regular array of circular structures ( $8 \mathrm{~nm}$ in diameter) associated with the outer membrane of the cell and present when the outer membrane was distorted or showing "blebbing", could be an $\mathrm{S}$ layer, i.e., a regular array of glycoproteins external to the outer membrane surface. $^{33}$

Freeze fracture preparations revealed the existence of concave structures at sites associated with flagellar insertions (figs. $2 \mathrm{E}$ and $2 \mathrm{~F}$ ) and these resemble the socalled "Coulton-Murray" studs seen in Aquaspirillum spp. $^{33}$ Similar structures have also been found associated with the flagella of $H$. felis. ${ }^{10}$ In both instances the diameter of these structures corresponds with the diameter of the flagella, which supports the concept of Coulton and Murray that these "studs" are associated with the basal organelle of the flagella. It has recently been reported that similar structures now seen in $E$. coli were absent in mutants which lacked genes responsible for flagellar function. ${ }^{28}$

The paddles reported on the flagella of $H$. pylori and $H$. mustelae ${ }^{19}$ were rarely seen in our negatively stained preparations; however, in the thin sections of bacterial cultures, these structures were observed more frequently (fig. 3). The exact location of the paddles with respect to the ends of the flagella could not be determined due to the nature of this preparation. Two differently shaped paddles were observed, circular and oval, but neither approach the size of the large paddles reported in $H$. pylori by Steer ${ }^{34}$ In addition, we commonly found similar structures or thickening of flagella quite close to the cell wall and associated with the broken end of a flagellum. The paddles may not be restricted to the terminal end of a flagellum, but may result from physical changes to the flagella if they are broken or fractured or they may be an artefact of electronmicroscopy. Indeed, the regularity with which we noticed such paddle-like structures in sections of $H$. mustelae and the variation in the size of the paddles reported in the literature would support this latter premise. The inclusion of ruthenium red in the initial fixation confirmed the presence of a glycocalyx external to the outer membrane, as has been previously reported. ${ }^{35}$

A detailed examination of the association of $H$. mustelae with ferret gastric tissue at an ultrastructure level has not yet been reported. We stated previously that $H$. mustelae adheres and partly penetrates epithelial cells with microvilli surrounding the bacteria. ${ }^{14}$ These observations can now be expanded revealing similarities and differences between the association of $H$. mustelae with ferret gastric tissue and $H$. pylori with human gastric tissue. In the present study, $H$. mustelae was observed aligned along microvilli connected by fibrous strands of glycocalyx (fig. 4). In some instances, the association between the bacterium and the epithelium surface was more direct, occasionally resulting in the formation of pedestals (fig. 4). It has been postulated that pedestals are an extrusion of the cytoplasm resulting from damage to the plasma membrane by toxin produced by the bacteria..$^{36}$ However, whereas $H$. pylori is known to possess cytotoxic activity, ${ }^{37}$ no $H$. mustelae cytotoxin has been detected. $^{38}$

$H$. pylori has been found only rarely intracellularly and then in association with ulcers. ${ }^{16,34}$ The majority of $H$. pylori are found in the overlying mucus with 3-19\% of bacteria in biopsies estimated to be adherent to epithelial cells. ${ }^{39}$ The proportion of adherent cells is the most striking difference observed between $H$. pylor $i$ and $H$. mustelae in tissue specimens. $H$. mustelae is almost exclusively found in association with the epithelial surface, with very few bacteria in the overlying mucus. Furthermore, in ferret tissue, the bacteria are observed in membrane-bound inclusions. Evans et al. ${ }^{\mathbf{4 0}}$ have shown that $H$. pylori can be internalised in vitro and they have proposed that receptor-mediated endocytosis occurs. Endocytosis is involved in the pathogenicity of many bacteria ${ }^{41}$ but its role in the pathogenesis of infection with Helicobacter spp. needs further study.

Demonstration of what appears to be specific adhesion and endocytosis of $H$. mustelae in the gastric mucosa is important, since it will provide a convenient animal model to assess the role of adhesion in pathogenesis. Significantly, our studies with $H$. felis and " $G$. hominis" have shown that these bacteria do not adhere to gastric surfaces yet they are capable of inducing gastritis, which suggests that adhesion may not be essential for gastric colonisation or induction of gastric inflammation. ${ }^{42,43}$ However, $H$. pylori and $H$. mustelae are the only gastric bacteria shown to adhere to the surface of gastric mucosa and are the only bacteria shown to be associated with peptic ulceration; adhesion may be important in ulceration.

In other studies we have confirmed the presence of adhesins in $H$. pylori and $H$. mustelae but not in $H$. felis. Various isolates of $H$. pylori and $H$. mustelae agglutinated red blood cells from man and animals but no such activity was observed in the four isolates of $H$. felis tested. ${ }^{44}$

The more we understand the association of Helicobacter spp. with the gastric surface, the more easily we will be able to devise appropriate prophylactic and therapeutic strategies for the prevention of $\mathrm{H}$. pyloriinduced gastroduodenal disease. 
We acknowledge the help of S. Kouprach, Biomedical Electron Microscope Unit, University of NSW, in the preparation of the freeze-fracture specimens. This work was supported by a grant from the National Health and Medical Research Council of Australia and Proctor and Gamble and, in part, by Public Health Service Grants
R01-A125631 from the National Institute of Allergy and Infectious Diseases, P01-CA-26731 from the National Cancer Institute, and RR1046-14 and T32-RR07036-02 from the Division of Research Resources.

\section{References}

1. Marshall BJ, Royce H, Annear DI et al. Original isolation of Campylobacter pyloridis from human gastric mucosa. Microbios Lett 1984; 25 : 83-88.

2. Rappin JP. Contr a l'étude de bacterium de la bouche a l'etat normal, 1881, 68. Cited by Breed RS, Murray EDG, Hitchens AP in Bergey's Manual of determinative bacteriology, 6th edn. Baltimore, Williams and Wilkins. 1948: 217.

3. Salomon H. Ueber das Spirillam des Säugetiermagens und sien Verhalten zu den Belegzellen. Zentralbl Bakteriol 1896; 19: 433-442.

4. Lim RKS. A parasitic spiral organism in the stomach of the cat. Parasitology 1920; 12: 108-112.

5. Doenges JL. Spirochetes in the gastric glands of macacus rhesus and of man without related disease. Arch Pathol 1939; 27: $469-477$.

6. Baskerville A, Newell DG. Naturally occurring chronic gastritis and $C$. pylori infection in the Rhesus monkey; a potential model for gastritis in man. Gut 1988; 29 : 465-472.

7. Bronsdon MA, Goodwin CS, Sly LI, Chilvers T, Schoenknecht FD. Helicobacter nemestrinae sp. nov., a spiral bacterium found in the stomach of a pigtailed macaque (Macaca nemestrina). Int J Syst Bacteriol 1991; 41 : 148-153.

8. Curry A, Jones DM, Eldridge J. Spiral organisms in the baboon stomach. Lancet 1987; 2: 634-635.

9. Fox JG, Edrise BM, Cabot EB, Beaucage C, Murphy JC, Prostak KS. Campylobacter-like organisms isolated from gastric mucosa of ferrets. Am J Vet Res 1986; 47: 236-239.

10. Lee A, Hazell SL, O'Rourke J, Kouprach S. Isolation of a spiral-shaped bacterium from the cat stomach. Infect Immun 1988; 56: 2843-2850.

11. Fox JG, Chilvers T, Goodwin CS et al. Campylobacter mustelae, a new species resulting from the elevation of Campylobacter pylori subsp. mustelae to species status. Int J Syst Bacteriol 1989; 39: 301-303.

12. Paster BJ, Lee A, Fox JG et al. Phylogeny of Helicobacter felis sp. nov., Helicobacter mustelae, and related bacteria. Int $J$ Syst Bacteriol 1991; 41 : 31-38.

13. Karnovsky MS. A formaldehyde-glutaraldehyde fixative of high osmolarity for use in electron microscopy. J Cell Biol 1965; $27: 137 \mathrm{~A}-138 \mathrm{~A}$.

14. Fox JG, Correa P. Taylor NS et al. Helicobacter mustelaeassociated gastritis in ferrets: an animal model of Helicobacter pylori gastritis in man. Gastroenterology 1990; 99: 352-361.

15. Hazell SL, Lee A, Brady L, Hennessy W. Campylobacter pyloridis and gastritis: association with intercellular spaces and adaption to an environment of mucus as important factors in colonization of the gastric epithelium. $J$ Infect Dis 1986; 153: 658-663.

16. Chen XG, Correa P, Offerhaus $\mathrm{J}$ et al. Ultrastructure of the gastric mucosa harboring Campylobacter-like organisms. Am J Clin Pathol 1986; 86: 575-582.

17. Savage DC. Microbial ecology of the gastrointestinal tract. Annu Rev Microbiol 1977; 31 : 107-133.

18. Lee A. Normal flora of animal intestinal surfaces. In : Bitton G, Marshall KC (eds) Adsorption of microorganisms to surfaces. New York, John Wiley and Sons. 1980: 145-173.

19. Goodwin CS, Armstrong JA, Chilvers T et al. Transfer of Campylobacter pylori and Campylobacter mustelae to Helicobacter gen. nov. and Helicobacter pylori comb. nov. and Helicobacter mustelae comb. nov., respectively. Int $J$ Syst Bacteriol 1989; 39 : 397-405.

20. Vandamme P, Falsen E, Rossau R et al. Revision of Campylobacter, Helicobacter and Wolinella taxonomy: emendation of generic descriptions and proposal of Arcobacter gen. nov. Int J Syst Bacteriol 1991; 41: 88-103.

21. McNulty CAM, Dent JC, Curry A et al. New spiral bacterium in gastric mucosa. J Clin Pathol 1989; 42: 585-591.

22. Dick E, Lee A, Watson G, O'Rourke J. Use of the mouse for the isolation and investigation of stomach-associated, spiralhelical shaped bacteria from man and other animals. $J$ Med Microbiol 1989; 29: 55-62.

23. Leifson E. Atlas of bacterial flagellation. New York, Academic Press. 1960: 8-13.

24. Greenberg EP, Canale-Parola E. Relationship between cell coiling and motility of Spirochaetes in viscous environments. J Bacteriol 1977; 131 : 960-969.

25. Greenberg EP, Canale-Parola E. Motility of flagellated bacteria in viscous environments. $J$ Bacteriol $1977 ; 132$ : 356-358.

26. Ferrero RL, Lee A. Motility of Campylobacter jejuni in a viscous environment: comparison with conventional rodshaped bacteria. J Gen Microbiol 1988; 134: 53-59.

27. DePamphilis ML, Adler J. Attachment of flagella basal bodies to the cell envelope: specific attachment to the outer, lipopolysaccharide membrane and the cytoplasmic membrane. J Bacteriol 1971; 105: 396-407.

28. MacNab RM, DeRosier DJ. Bacterial flagellar structure and function. Can J Microbiol 1988; 34: 442-451.

29. Coulton JW, Murray RGE. Cell envelope associations of Aquaspirillum serpens flagella. $J$ Bacteriol 1978; 136: 1037-1049.

30. Swann MA. Electron microscopic observations of structures associated with the flagella of Spirillum volutans. $J$ Bacteriol 1985; 161 : 1137-1145.

31. Rowles CR, Parton R, Jeynes MH. Some aspects of the cell walls of Vibrio spp. In: Fuller R, Lovelock DW (eds) Microbial ultrastructure: the use of the electron microscope. London, Academic Press. 1976: 109-115.

32. Jones DM, Curry A, Fox AJ. An ultrastructural study of the gastric campylobacter-like organism 'Campylobacter pyloridis'. J Gen Microbiol 1985; 131 : 2335-2341.

33. Costerton JW, Irvin RT, Cheng K-J. The role of bacterial surface structures in pathogenesis. CRC Crit Rev Microbiol $1981 ; 8$ : $303-338$.

34. Steer HW. Ultrastructure of Campylobacter pylori in vivo. In: Rathbone BJ, Heatley RV (eds) Campylobacter pylori and gastroduodenal disease. Oxford, Blackwell Scientific Publications. 1989: 146-154.

35. Goodwin CS. Microbiology of C. pylori. In: Blaser MJ (ed) Campylobacter pylori in gastritis and peptic ulcer disease. New York, Igaku-Shoin Medical Publishers. 1989: 25-50.

36. Cantey JR, Lushbaugh WB, Inman LR. Attachment of bacteria to intestinal epithelial cells in diarrhea caused by Escherichia coli strain RDEC-1 in rabbits: stages and role of capsule. $J$ Infect Dis $1981 ; 143: 219-230$.

37. Leunk RD, Johnson PT, David BC, Kraft WG, Morgan DR. Cytotoxic activity in broth-culture filtrates of Campylobacter pylori. J Med Microbiol 1988; 26: 93-99.

38. Morgan DR, Fox JG, Leunk RD. Comparison of isolates of Helicobacter pylori and Helicobacter mustelae. J Clin Microbiol 1991; 29: 395-397.

39. Hessey SJ, Spencer J, Wyatt JI et al. Bacterial adhesion and disease activity in Helicobacter-associated chronic gastritis. Gut 1990; 31 : 134-138.

40. Evans DG, Evans DJ, Graham DY. Internalization of Helicobacter pylori by HEp-2 cells. Rev Esp Ent Digest 1990: $78: 56$.

41. Findlay BB, Falkow S. Common themes in microbial pathogenicity. Microbiol Rev 1989; 53: 210-230.

42. Lee A, Fox JG, Otto G, Murphy, J. A small animal model of human Helicobacter pylori active chronic gastritis. Gastroenterology 1990; 99: 1315-1323.

43. Lee A, Eckstein RP, Fevre DI, Dick E, Kellow JE. Non Campylobacter pylori spiral organisms in the gastric antrum. Aust NZ J Med 1989; 19: 156-158.

44. Taylor NS, Hasubski AT, Fox JG, Lee A. Haemagglutination profiles of Helicobacter species that cause gastritis in man and animals. $J$ Med Microbiol 1992; 37: in press. 